ISSN: 2231-3354

Received on: 06-08-2012

Revised on: 13-08-2012

Accepted on: 18-08-2012

DOI : 10.7324/] APS.2012.2840

Anand B. Pandya, Dhaval G. Prajapeti and Saurabh S. Pandya Department of Pharmacentical Chemistry, Nutan Education Trust's, B.P harmacy College, Rampura, K akanpur, Godhra-389713, Gujarat, India.
For Correspondence Anand B.Pandya,

E-mail: anand_pandya@live com Phone +91-8000656594

\section{Synthesis of novd Naphthalene COX inhibitors for anti-inflammatory activity}

\author{
Anand B. Pandya, Dhaval G. Prajapati and Sauraldh S. Pandya
}

\begin{abstract}
Inflammation forms the part of various diseased conditions. To treat inflammation variet of anti inflammatory agents are synthesized, they showed undesirable side effects. In order to avoi these side effects, nonsteroidal anti-inflammatory drugs were developed. Research is a continuou and never ending process; efforts are being made to improve the present drug profile such tha present side effects can be eliminated. Syntheses of number of naphthalene derivatives wit pyrazole moiety were completed. The present classification records for numerous naphthalen derivatives (naproxen and nabumetone) and also many anti-inflammatory drugs containing diary heterocycle(celecoxib,rofecoxib) are available as reference, therefore some new non-vicinal 3,5 diaryl heterocycles, in which naphthalene as one of aryl ring and pyrazole as central scaffold wa prepared and evaluated for anti-inflammatory activity. The purity of all compounds has bee examined by the TLC and structure is confirmed by different analytical techniques like IR, Mas spectroscopy and NMR. Further, the synthesized drugs were evaluated for in vivo anti inflammatory activity by carrageenan induced rat paw edema test using Indomethacin as a standar drug. In conclusion, we have found that two compounds showed equipotent activity while othe two showed slightly more anti-inflammatory activity respectively.
\end{abstract}

Keywords: Naphthalene, pyrazole, non-vicinal 3, 5-diaryl heterocyclic, anti-inflammatory activity

\section{INTRODUCTION}

Inflammation is part of the complex biological response of vascular tissues to harmful stimuli, such as pathogens, damaged cells, or irritants. Inflammation is a protective attempt by the organism to remove the injurious stimuli and to initiate the healing process (Rang et al, 2003). Inflammation is not a synonym for infection, even in cases where inflammation is caused by infection (Cuzzocrea et al, 2005) . To treat inflammation various treatment are available like glucocorticoid cortisol, Nonsteroidal antiinflammatory drugs (NSAIDs) like aspirin, ibuprofen and a number of proteins produced by recombinant DNA technology. Naphthalene is important aryl ring in many active compounds such as anti-inflammatory, anti-bacterial, anti-microbial and anti-cancer . In recent trends, heterocycles plays a major role in drug synthesis (Joan.F et al, 2001, Kunal et al, 2011, Lake et al, 2011 and Sharma et al, 2011). Pyrazole derivatives have been the subject of substantial attention by synthetic and medicinal chemists because of the role of this heteroaromatic ring in many biological activities such as anticancer, antiviral , antiinflammatory, antifungal , antimicrobial , antihistaminic, antiplatelet and analgesic activities (Chauhan et al, 2011) 
In particular some of naphthalene derivatives were in depth investigated as nonsteroidal anti inflammatory drugs (NSAIDs) . The mechanism of action of this class of compounds is linked to the nonselective or selective inhibition of two cyclooxygenase isoform, COX-1 \& COX-2 (J.R.Vane et al,1998, Palwinder singh et al, 2008 and Anna Blobaum et al, 2007) . Even the literature survey supports that pyrazole containing moiety gave anti-inflammatory activity by acting on COX enzyme(Youssef et al, 2010, Sakya et al, 2006 , Amir et al, 2005, Dekhane et al, 2011, Kobayashi et al, 2009, Barsoum et al, 2009,Bechit et al, 2008, Engman et al, 1995, Nagarapu et al, 2011 ) etc . Thus synthesizing non-vicinal diaryl pyrazole is a novel approach. So the aim has been designed to synthesize 2-(5substituted-1H-pyrazol-3-yl) naphthalen-1-ol for safer and potential anti-inflammatory agents .

\section{MATERIALS AND METHODS}

The chemicals employed in the synthetic work were purchased from Chemco Fine Chemicals Factory, Mumbai. The solvents AR grades were obtained from Qualikems Fine Chemicals Pvt. Ltd., New Delhi. Thin layer chromatography was performed on aluminium sheet $(2 \times 5 \mathrm{~cm})$ coated with silica gel 60 $\mathrm{F}_{254}$, marketed by Merck Specialities Private Ltd. and spots were visualized under UV light and by exposure to iodine vapour. FTIR spectra were recorded in $\mathrm{KBr}$ powder on a Jasco V460 IR Specrmeter by diffused reflectance technique. Mass spectra were recorded on a prostar binary-410 LC with 500 IT PDA detector and spectrum was taken by direct infusion mass with ESI and APCI positive and negative mode ionization ranging from 500-2000 m/e. Elemental (C, H, N) analyses were obtained on Vario EL III Elementar ${ }^{1} \mathrm{H}$ - NMR spectra were measured in $\mathrm{d}_{6}$-DMSO on a Bruker II Avance $400 \mathrm{MHz}$ NMR spectrometer. The reported chemical shifts were against TMS.

\section{Chemistry}

General procedure Synthesis of 2-(5-substituted-1Hpyrazol-3-yl) naphthalen-1-ol was carried out by Friedal Craft $\alpha$ - naphthol proceeded to esterification by various benzoic acid derivatives to yield various naphthyl esters. Naphthyl esters underwent base catalysed Baker-venkatraman rearrangement reaction to give 1, 3-diketones. Further 1, 3-diketones were refluxed with hydrazine hydrate gave 3, 5-disubstituted pyrazole as shown in the synthetic scheme.

\section{Synthesis of 1-(1-hydroxynaphthalen-2-yl) ethanone}

(Vyawhare et al, 2010) was carried out by the following procedure: In $80 \mathrm{ml}$ hot glacial acetic acid, $50 \mathrm{gm}$ zinc chloride was added and the reaction mixture was refluxed till it dissolved. Then $30 \mathrm{gm}$ of 1-naphthol was added to reaction mixture and was refluxed for $8 \mathrm{hrs}$. The reaction mixture was cooled and poured in acidulated water. The crude product was filtered, washed with water and recrystallized from ethanol to obtain pure product of $93.5 \%$ w/w yield having m.p. $82-85^{\circ} \mathrm{C}$. (Table: 1 )

Table. 1: Analysis for 1-(1-hydroxynaphthalen-2-yl) ethanone.

\begin{tabular}{ll}
\hline \multicolumn{1}{c}{ PARAMETERS } & \multicolumn{1}{c}{ RESULT } \\
\hline Molecular formula & $\mathrm{C}_{12} \mathrm{H}_{10} \mathrm{O}_{2}$ \\
Molecular weight & $186.21 \mathrm{gm} / \mathrm{mole}$ \\
Percentage Yield & $93.5 \% \mathrm{w} / \mathrm{w}$ \\
Melting Point & $82-85^{\circ} \mathrm{C}$ \\
Recrystallization solvent & Ethanol \\
Rf value & 0.70 \\
Mobile phase & Chloroform \\
\hline
\end{tabular}

\section{Synthesis of 2-acetylnaphthalen-1-yl substituted benzoate}

(Yadav et al, 2012) In 100-ml of two necked RBF having dropping funnel and calcium guard tube, place $1.86 \mathrm{gm}(0.01 \mathrm{~mole})$ of 1-(1-hydroxynaphthalen-2-yl) ethanone and 0.015 mole of substituted benzoic acid in $3.72 \mathrm{ml}$ of dry pyridine.Stirr the mixture at $0^{\circ}-5^{\circ} \mathrm{C}$ for near about 15 minutes. Add $1.49 \mathrm{ml}(2.46 \mathrm{gm}, 0.016$ moles) of dry phosphorus oxychloride drop wise during 2 hours. When the addition was over, the mixture was poured with good stirring into ice-cold hydrochloric acid, followed by small volume of ice-cold water. The product was collected on a Buchner funnel with the help of vacuum pump. Washing was continued till no more pyridine smell was present. The product was dried at room temperature and recrystallized from methanol. (Table: 2)

\begin{tabular}{|c|c|c|c|c|c|c|}
\hline Compound Code & $-\mathbf{X}$ & Molecular Formula & Molecular Weight (gm/mole) & Melting Point $\left({ }^{\circ} \mathrm{C}\right)$ & $\%$ Yield(w/w) & Rf value \\
\hline $5 a$ & $-\mathrm{H}$ & $\mathrm{C}_{19} \mathrm{H}_{14} \mathrm{O}_{3}$ & 290.3 & $70-72$ & 94.35 & 0.73 \\
\hline $5 b$ & $-\mathrm{Br}$ & $\mathrm{C}_{19} \mathrm{H}_{13} \mathrm{BrO}_{3}$ & 368.0 & $176-178$ & 76.53 & 0.75 \\
\hline $5 c$ & $-F$ & $\mathrm{C}_{19} \mathrm{H}_{13} \mathrm{FO}_{3}$ & 308.1 & $170-175$ & 78.89 & 0.77 \\
\hline $5 d$ & $-\mathrm{Cl}$ (ortho) & $\mathrm{C}_{19} \mathrm{H}_{13} \mathrm{ClO}_{3}$ & 324.6 & $100-103$ & 56.78 & 0.74 \\
\hline $5 e$ & $-\mathrm{CH}_{3}$ & $\mathrm{C}_{20} \mathrm{H}_{16} \mathrm{O}_{3}$ & 304.1 & $75-78$ & 84.56 & 0.68 \\
\hline $5 f$ & $-\mathrm{NO}_{2}$ (meta) & $\mathrm{C}_{19} \mathrm{H}_{13} \mathrm{NO}_{5}$ & 335.5 & $150-154$ & 70.85 & 0.79 \\
\hline $5 g$ & 3,5-dinitro & $\mathrm{C}_{19} \mathrm{H}_{13} \mathrm{~N}_{2} \mathrm{O}_{7}$ & 380.1 & $180-182$ & 65.5 & 0.71 \\
\hline $5 \mathrm{~h}$ & -OH (ortho) & $\mathrm{C}_{19} \mathrm{H}_{14} \mathrm{O}_{4}$ & 306.1 & $115-118$ & 60.70 & 0.74 \\
\hline
\end{tabular}

Mobile phase:-Chloroform:Benzene(7:3)

\begin{tabular}{|c|c|c|c|c|c|c|}
\hline Compound Code & $-\mathbf{X}$ & Molecular Formula & Molecular Weight (gm/mole) & Melting Point $\left({ }^{\circ} \mathrm{C}\right)$ & $\%$ Yield (w/w) & Rf value \\
\hline $6 a$ & $-\mathrm{H}$ & $\mathrm{C}_{19} \mathrm{H}_{14} \mathrm{O}_{3}$ & 290.3 & $72-75$ & 74.8 & 0.67 \\
\hline $6 b$ & $-\mathrm{Br}$ & $\mathrm{C}_{19} \mathrm{H}_{13} \mathrm{BrO}_{3}$ & 368.0 & $180-182$ & 84.2 & 0.65 \\
\hline $6 \mathrm{c}$ & $-F$ & $\mathrm{C}_{19} \mathrm{H}_{13} \mathrm{FO}_{3}$ & 308.1 & $170-172$ & 56.2 & 0.71 \\
\hline $6 \mathrm{~d}$ & $-\mathrm{Cl}$ (ortho) & $\mathrm{C}_{19} \mathrm{H}_{13} \mathrm{ClO}_{3}$ & 324.6 & $90-94$ & 70.5 & 0.70 \\
\hline $6 e$ & $-\mathrm{CH}_{3}$ & $\mathrm{C}_{20} \mathrm{H}_{16} \mathrm{O}_{3}$ & 304.1 & $80-85$ & 65.4 & 0.65 \\
\hline $6 f$ & $-\mathrm{NO}_{2}$ (meta) & $\mathrm{C}_{19} \mathrm{H}_{13} \mathrm{NO}_{5}$ & 335.5 & $160-163$ & 74.87 & 0.74 \\
\hline $6 \mathrm{~g}$ & 3,5-dinitro & $\mathrm{C}_{19} \mathrm{H}_{13} \mathrm{~N}_{2} \mathrm{O}_{7}$ & 380.1 & 190-194 & 66.5 & 0.65 \\
\hline $6 \mathrm{~h}$ & $-\mathrm{OH}$ (ortho) & $\mathrm{C}_{19} \mathrm{H}_{14} \mathrm{O}_{4}$ & 306.1 & $118-120$ & 58.8 & 0.72 \\
\hline
\end{tabular}


Table. 4: Analytical Table for 2-(5-substituted-1H-pyrazol-3-yl) naphthalen-1-ol.

\begin{tabular}{|c|c|c|c|c|c|c|}
\hline Compound Code & $-\mathbf{X}$ & Molecular Formula & Molecular Weight (gm/mole) & Melting Point $\left({ }^{\circ} \mathrm{C}\right)$ & $\%$ Yield (w/w) & Rf value \\
\hline $7 \mathrm{a}$ & $-\mathrm{H}$ & $\mathrm{C}_{19} \mathrm{H}_{14} \mathrm{~N}_{2} \mathrm{O}$ & 286.3 & $160-162$ & 60.74 & 0.70 \\
\hline $7 b$ & $-\mathrm{Br}$ & $\mathrm{C}_{19} \mathrm{H}_{13} \mathrm{~N}_{2} \mathrm{BrO}$ & 365.2 & $187-190$ & 75.65 & 0.74 \\
\hline $7 \mathrm{c}$ & $-F$ & $\mathrm{C}_{19} \mathrm{H}_{13} \mathrm{~N}_{2} \mathrm{FO}$ & 304.3 & $170-172$ & 74.88 & 0.78 \\
\hline $7 d$ & $-\mathrm{Cl}$ (ortho) & $\mathrm{C}_{19} \mathrm{H}_{13} \mathrm{~N}_{2} \mathrm{ClO}$ & 320.8 & $140-143$ & 48.5 & 0.69 \\
\hline $7 \mathrm{e}$ & $-\mathrm{CH}_{3}$ & $\mathrm{C}_{20} \mathrm{H}_{16} \mathrm{~N}_{2} \mathrm{O}$ & 300.4 & $160-163$ & 79.8 & 0.65 \\
\hline $7 f$ & $-\mathrm{NO}_{2}$ (meta) & $\mathrm{C}_{19} \mathrm{H}_{13} \mathrm{~N}_{3} \mathrm{O}_{3}$ & 331.3 & $180-182$ & 35.6 & 0.77 \\
\hline $7 \mathrm{~g}$ & 3,5-dinitro & $\mathrm{C}_{19} \mathrm{H}_{12} \mathrm{~N}_{4} \mathrm{O}_{5}$ & 376.4 & $191-193$ & 39.74 & 0.76 \\
\hline $7 \mathrm{~h}$ & $-\mathrm{OH}$ (ortho) & $\mathrm{C}_{19} \mathrm{H}_{14} \mathrm{~N}_{2} \mathrm{O}_{2}$ & 302.3 & $130-132$ & 40.4 & 0.64 \\
\hline
\end{tabular}

Mobile phase:-Chloroform:Benzene( $7: 3)$

Table. 5: Spectral characteristics for 2-(5-substituted-1H-pyrazol-3-yl) naphthalene-1-ol

\begin{tabular}{|c|c|c|c|c|}
\hline Compound Code & $-\mathbf{X}$ & $\operatorname{IR}\left(\mathrm{cm}^{-1}\right)$ & Mass Spectra & ${ }^{1} \mathrm{H}$ NMR(ppm) \\
\hline $7 \mathrm{a}$ & $-\mathrm{H}$ & $\begin{array}{l}-\mathrm{OH}(3610-3620) \\
-\mathrm{C}-\mathrm{H} \operatorname{str}(3050) \\
-\mathrm{C}=\mathrm{C}-\operatorname{Aromatic}(1470 \& 1600) \\
-\mathrm{C}=\mathrm{N}(1650)\end{array}$ & $\begin{array}{c}287.3\left(\mathrm{M}^{+}+1\right) \\
286.1\left(\mathrm{M}^{+}\right)\end{array}$ & $\begin{array}{c}\text { 7.2-8.3(m,12H,Ar) } \\
9.82(\mathrm{w}, 1 \mathrm{H},-\mathrm{OH}) \\
13.2(\mathrm{w}, 1 \mathrm{H},-\mathrm{NH})\end{array}$ \\
\hline $7 b$ & $-\mathrm{Br}$ & $\begin{array}{l}-\mathrm{OH}(3620-3640) \\
-\mathrm{C}-\mathrm{H} \operatorname{str}(3090) \\
-\mathrm{C}=\mathrm{C}-\operatorname{Aromatic}(1470 \& 1590) \\
-\mathrm{C}=\mathrm{N}(1650) \\
-\mathrm{C}-\mathrm{Br}(600)\end{array}$ & $\begin{array}{l}366.2\left(\mathrm{M}^{+}+1\right) \\
367.3\left(\mathrm{M}^{+}+2\right)\end{array}$ & $\begin{array}{c}6.8-8.1(\mathrm{~m}, 11 \mathrm{H}, \mathrm{Ar}) \\
8.89(\mathrm{w}, 1 \mathrm{H},-\mathrm{OH}) \\
13.1(\mathrm{w}, 1 \mathrm{H},-\mathrm{NH})\end{array}$ \\
\hline $7 \mathrm{c}$ & $-\mathrm{F}$ & $\begin{array}{l}-\mathrm{OH}(3640-3650) \\
-\mathrm{C}-\mathrm{H} \operatorname{str}(3100) \\
-\mathrm{C}=\mathrm{C}-\text { Aromatic }(1470 \& 1610) \\
-\mathrm{C}=\mathrm{N}(1655) \\
-\mathrm{C}-\mathrm{F}(1200)\end{array}$ & $\begin{array}{l}305.9\left(\mathrm{M}^{+}+1\right) \\
306.2\left(\mathrm{M}^{+}+2\right)\end{array}$ & $\begin{array}{c}6.8-8.3(\mathrm{~m}, 11 \mathrm{H}, \mathrm{Ar}) \\
8.92(\mathrm{w}, 1 \mathrm{H},-\mathrm{OH}) \\
12.9(\mathrm{w}, 1 \mathrm{H},-\mathrm{NH})\end{array}$ \\
\hline $7 d$ & $-\mathrm{Cl}$ (ortho) & $\begin{array}{l}-\mathrm{OH}(3520-3495) \\
-\mathrm{C}-\mathrm{H} \operatorname{str}(3110) \\
-\mathrm{C}=\mathrm{C}-\operatorname{Aromatic}(1470 \& 1590) \\
-\mathrm{C}=\mathrm{N}(1645) \\
-\mathrm{C}-\mathrm{Cl}(800)\end{array}$ & $\begin{array}{l}321.6\left(\mathrm{M}^{+}+1\right) \\
322.1\left(\mathrm{M}^{+}+2\right)\end{array}$ & $\begin{array}{c}6.7-8.4(\mathrm{~m}, 11 \mathrm{H}, \mathrm{Ar}) \\
9.73(\mathrm{w}, 1 \mathrm{H},-\mathrm{OH}) \\
13.7(\mathrm{w}, 1 \mathrm{H},-\mathrm{NH})\end{array}$ \\
\hline $7 \mathrm{e}$ & $-\mathrm{CH}_{3}$ & $\begin{array}{l}-\mathrm{OH}(3310-3290) \\
-\mathrm{C}-\mathrm{H} \operatorname{str}(3070) \\
-\mathrm{C}=\mathrm{C}-\operatorname{Aromatic}(1470 \& 1600) \\
-\mathrm{C}=\mathrm{N}(1655)\end{array}$ & $\begin{array}{c}301.5\left(\mathrm{M}^{+}+1\right) \\
300.4\left(\mathrm{M}^{+}\right) \\
284.9(\mathrm{M}-15)\end{array}$ & $\begin{array}{c}6.6-8.3(\mathrm{~m}, 11 \mathrm{H}, \mathrm{ArOH}) \\
9.82(\mathrm{w}, 1 \mathrm{H},-\mathrm{OH}) \\
13.2(\mathrm{w}, 1 \mathrm{H},-\mathrm{NH}) \\
2.89\left(\mathrm{~s}, 2 \mathrm{H},-\mathrm{CH}_{3}\right)\end{array}$ \\
\hline $7 f$ & $-\mathrm{NO}_{2}$ (meta) & $\begin{array}{l}-\mathrm{OH}(3610-3620) \\
-\mathrm{C}-\mathrm{H} \operatorname{str}(3050) \\
-\mathrm{C}=\mathrm{C}-\operatorname{Aromatic}(1470 \& 1600) \\
-\mathrm{C}=\mathrm{N}(1650) \\
-\mathrm{NO}_{2}(1485)\end{array}$ & $332.4\left(\mathrm{M}^{+}+1\right)$ & $\begin{array}{c}7.2-8.3(\mathrm{~m}, 10 \mathrm{H}, \mathrm{Ar}) \\
3.2-3.8\left(\mathrm{~s}, 1 \mathrm{H},-\mathrm{CH}_{2-}\right) \\
9.72(\mathrm{w}, 1 \mathrm{H},-\mathrm{OH}) \\
13.1(\mathrm{w}, 1 \mathrm{H},-\mathrm{NH})\end{array}$ \\
\hline $7 \mathrm{~g}$ & 3,5-dinitro & $\begin{array}{l}-\mathrm{OH}(3610-3620) \\
-\mathrm{C}-\mathrm{H} \operatorname{str}(3050) \\
-\mathrm{C}=\mathrm{C}-\operatorname{Aromatic}(1470 \& 1600) \\
-\mathrm{C}=\mathrm{N}(1650) \\
-\mathrm{NO}_{2}(1490)\end{array}$ & $376.4\left(\mathrm{M}^{+}+1\right)$ & $\begin{array}{c}7.1-8.8(\mathrm{~m}, 10 \mathrm{H}, \mathrm{Ar}) \\
3.1-3.9\left(\mathrm{~s}, 1 \mathrm{H},-\mathrm{CH}_{2-}\right) \\
9.88(\mathrm{w}, 1 \mathrm{H},-\mathrm{OH}) \\
13.3(\mathrm{w}, 1 \mathrm{H},-\mathrm{NH})\end{array}$ \\
\hline $7 \mathrm{~h}$ & $-\mathrm{OH}$ (ortho) & $\begin{array}{l}-\mathrm{OH}(3610-3620) \\
-\mathrm{C}-\mathrm{H} \operatorname{str}(3050) \\
-\mathrm{C}=\mathrm{C}-\text { Aromatic }(1470 \& 1600) \\
-\mathrm{C}=\mathrm{N}(1650) \\
-\mathrm{C}-\mathrm{OH}(3200-3210) \text { broad peak }\end{array}$ & $303.6\left(\mathrm{M}^{+}+1\right)$ & $\begin{array}{c}\text { 7.2-8.3(m,12H,Ar) } \\
9.81(\mathrm{w}, 1 \mathrm{H},-\mathrm{OH}) \\
13.2(\mathrm{w}, 1 \mathrm{H},-\mathrm{NH})\end{array}$ \\
\hline
\end{tabular}

Table. 6: Screening of Anti-inflammatory Activity in Albino Wistar Rat.

\begin{tabular}{|c|c|c|c|c|c|c|c|c|c|}
\hline \multirow{2}{*}{$\begin{array}{l}\text { Compound } \\
\text { Code }\end{array}$} & \multicolumn{5}{|c|}{ Inhibition of inflammation $(\mathrm{cm})$} & \multicolumn{4}{|c|}{ \% inhibition } \\
\hline & Ohr & 1hr & $2 \mathrm{hr}$ & $3 \mathrm{hr}$ & $4 \mathrm{Hr}$ & $1 \mathrm{hr}$ & $2 \mathrm{hr}$ & $3 \mathrm{hr}$ & $4 \mathrm{Hr}$ \\
\hline Control & $0.36 \pm 0.02$ & $0.33 \pm 0.02$ & $0.31 \pm 0.02$ & $0.30 \pm 0.02$ & $0.29 \pm 0.02$ & - & - & - & - \\
\hline Standard Indomethacin & $0.33 \pm 0.02$ & $0.30 \pm 0.02$ & $0.26 \pm 0.02$ & $0.23 \pm 0.02$ & $0.20 \pm 0.02$ & 9.09 & 16.12 & 23.33 & 31.03 \\
\hline $7 \mathrm{a}$ & $0.32 \pm 0.02$ & $0.28 \pm 0.02$ & $0.21 \pm 0.02$ & $0.18 \pm 0.02$ & $0.15 \pm 0.02$ & 15.15 & 32.25 & 40.00 & 48.27 \\
\hline $7 b$ & $0.33 \pm 0.02$ & $0.26 \pm 0.02$ & $0.19 \pm 0.02$ & $0.15 \pm 0.02$ & $0.09 \pm 0.02$ & 21.21 & 38.70 & 50.00 & 68.96 \\
\hline $7 \mathrm{c}$ & $0.32 \pm 0.02$ & $0.28 \pm 0.02$ & $0.21 \pm 0.02$ & $0.18 \pm 0.02$ & $0.14 \pm 0.02$ & 15.15 & 32.25 & 40.00 & 51.72 \\
\hline $7 d$ & $0.31 \pm 0.02$ & $0.27 \pm 0.02$ & $0.20 \pm 0.02$ & $0.15 \pm 0.02$ & $0.11 \pm 0.02$ & 18.20 & 35.48 & 50.00 & 62.06 \\
\hline $7 \mathrm{e}$ & $0.33 \pm 0.02$ & $0.30 \pm 0.02$ & $0.26 \pm 0.02$ & $0.21 \pm 0.02$ & $0.19 \pm 0.02$ & 9.09 & 16.12 & 30.00 & 34.48 \\
\hline $7 f$ & $0.33 \pm 0.02$ & $0.30 \pm 0.02$ & $0.28 \pm 0.02$ & $0.25 \pm 0.02$ & $0.22 \pm 0.02$ & 9.09 & 9.67 & 16.66 & 24.13 \\
\hline $7 \mathrm{~g}$ & $0.34 \pm 0.02$ & $0.31 \pm 0.02$ & $0.29 \pm 0.02$ & $0.26 \pm 0.02$ & $0.24 \pm 0.02$ & 6.06 & 6.45 & 13.33 & 17.24 \\
\hline $7 \mathrm{~h}$ & $0.31 \pm 0.02$ & $0.28 \pm 0.02$ & $0.26 \pm 0.02$ & $0.23 \pm 0.02$ & $0.20 \pm 0.02$ & 15.16 & 16.12 & 23.33 & 31.03 \\
\hline
\end{tabular}


Synthesis of 1-(1-hydroxynaphthalen-2-yl)-3-substituted propane-1, 3-dione ( $\beta$-diketone synthesis (Base-catalyzed BakerVenkataraman Rearrangement)

(Nopporn et al, 2002) : A solution of 0.01 mole of 2acetylnaphthalen-1-yl substituted benzoate in $11 \mathrm{ml}$ of dry pyridine was prepared in $100 \mathrm{ml} \mathrm{RBF}$ and warmed to $50^{\circ} \mathrm{C}$. To this solution $1 \mathrm{gm}$ of pulverized or fused $\mathrm{KOH}$ was added. The mixture was stirred for 15-30 minutes, during which time a copius precipitates of the yellow potassium salt of 1-(1-hydroxynaphthalen-2-yl)-3substituted propane-1, 3-dione( $\beta$-diketone) formed. The mixture was cooled to room temperature and acidified with ice cooled 100 $\mathrm{ml}$ of $10 \%$ hydrochloric acid .The diketone separated which was collected on a filter paper, dried and recrystallized with methanol .(Table : 3 )

\section{Synthesis of 2-(5-substituted-1H-pyrazol-3-yl) naphthalen-1-ol}

(Alhuwalia et al, 2006 )A mixture of the 0.0174 mole respective diketone, 0.022 mole hydrazine hydrochloride was refluxed in $15 \mathrm{ml}$ ethanol for 12 hours. After the completion of the reaction, the mixture was poured on to crushed ice acidify drop wise with acetic acid to check whether solution gets acidic $\mathrm{pH}$. The solid obtained was filtered, washed with water and recrystallized from methanol to give pure product. Table: 4 and Table: 5

\section{SCREENING OF ANTI-INFLAMMATORY ACTIVITY}

Anti-inflammatory activity for the prepared compounds was determined in vivo by the acute carrageenan induced paw edema standard method in rats. Wister albino rats of either sex (pregnant female animals were excluded) weighing 160-190 g were divided into 8 groups of 3 rats each. Administration of indomethacin (reference standard at a dose of $3 \mathrm{mg} / \mathrm{kg}$ of body weight) and the tested compounds dissolved in $1 \%$ tween 80 , at a dose of $3 \mathrm{mg} / \mathrm{kg}$ (body weight) was given intraperitoneally $1 \mathrm{~h}$ before induction of inflammation. The control group was given saline only. Carrageenan paws edema was induced by subcutaneous injection of $1 \%$ solution of carrageenan in saline $(0.1$ $\mathrm{ml} / \mathrm{rat}$ ) into the right hind paw of rats. Paw volumes were measured volumetrically after $1 \mathrm{~h}, 2 \mathrm{~h}, 3 \mathrm{~h}$ and $4 \mathrm{~h}$ of inflammation induction with Plethysmometer and compared with the initial hind paw volume (Table:6) of each rat for determining the edema volume (Vogel et al, 2008 and Winter et al, 1962). Data were collected, checked, revised and analyzed. Quantitative variables from normal distribution were expressed as means of SE "standard error".

The $\%$ inhibition of edema was calculated at the end of 4 hrs by using the formula

Percent $(\%)$ inhibition $=1-\mathrm{V}_{\mathrm{t}} / \mathrm{V}_{\mathrm{c}} \mathrm{X} 100$

Where $\mathrm{V}_{\mathrm{t}}$ - edema volume in test group,

$\mathrm{V}_{\mathrm{c}}$-edema volume in control group

Results were expressed as mean \pm standard deviation

\section{RESULTS AND DISCUSSIONS}

The purity of all the compounds were examined by TLC and structure confirmation was carried out by IR, Mass and $1 \mathrm{H}-$
NMR spectroscopy. Further the compounds were evaluated for invivo anti-inflammatory activity by acute carrageenan induced paw edema method in rats. It is concluded that target molecules, nonvicinal diaryl heterocycles have naphthalene moiety as one of the aryl group and substituted phenyl as the other aryl group with pyrazole as the central scaffold. Credible mechanism of action is predicted as same as that of vicinal diaryl heterocycles in NSAID class as in pyrazolone derivatives that acts by inhibiting COX-1 enzymes or by inhibiting selective COX-2 enzyme as in celecoxib, rofecoxib etc .As a result, it is predicted that the novel synthesized compounds acts by inhibiting either of the cyclooxygenase enzymes non-selectively. The pharmacological screening of the synthesized compounds showed anti-inflammatory activity ranging from $17.24 \%$ to $68.96 \%$ inhibition of rat paw edema volume after $4 \mathrm{hr}$, whereas the standard drug Indomethacin showed $31.03 \%$ inhibition of rat paw edema volume after $4 \mathrm{hr}$. Compound $7 \mathrm{a}, 7 \mathrm{~b}, 7 \mathrm{c}$ and $7 \mathrm{~d}$ were more potent than that of standard drug where as compound $7 \mathrm{e}$ and $7 \mathrm{~h}$ were equipotent and compound $7 \mathrm{f}$ and $7 \mathrm{~g}$ were less potent that than the standard drug.

\section{CONCLUSION}

In conclusion we have reported a facile route for the synthesis of 2-(5-substituted-1H-pyrazol-3-yl) naphthalen-1-ol which is a non vicinal diaryl heterocycle a novel moiety that was employed for the anti-inflammatory activity. The procedure for synthesizing 2-acetylnaphthalen-1-yl substituted benzoate is a critical one, as it is an exothermic reaction it is important to maintain the reaction temperature between $0-5^{\circ} \mathrm{C}$ and as the esters are water liable, the reaction condition must be anhydrous to aid in ester synthesis. Further it is advisable to use all the solvent in the freshly distilled and pure form. In final step of cyclization the reaction completion can be monitored by TLC and further structure can be confirmed by spectroscopic data. Further the compounds were evaluated for in-vivo anti-inflammatory activity by acute carrageenan induced paw edema standard method in rats. The pharmacological screening of the synthesized compounds showed wide range of anti-inflammatory activity. Comparatively the standard drug Indomethacin showed 31.03\% inhibition of rat paw edema volume after $4 \mathrm{hr}$. Compound $7 \mathrm{a}, 7 \mathrm{~b}, 7 \mathrm{c}$ and $7 \mathrm{~d}$ were more potent than that of standard drug where as compound $7 \mathrm{e}$ and $7 \mathrm{~h}$ were equipotent and compound $7 \mathrm{f}$ and $7 \mathrm{~g}$ were less potent that than the standard drug. Results of various compounds containing electron donating groups like methyl and halogen functional group are showed more activity than that of electron withdrawing groups nitro and dinitro functional group. From the obtained results, we can conclude that compound $7 \mathrm{~b}$ exhibited maximum activity. In future study, further detailed investigation on the mechanism of action and toxicity studies will be carried out and therapeutic index would be revealed for the synthesized drugs.

\section{ACKNOWLEDGEMENT}

The author Anand.B.Pandya is thankful to the project guide Dr. Dhaval.G.Prajapati, principal Dr. S.S.Pandya and all 
staff members of Nutan Education Trust, B.Pharmacy College, Rampura, Godhra, to fulfill the necessary requirements needed for the project successfully. I expand my thanks to CPCSEA committee for providing animal facilities for my project. Also thankful to Centre of Excellence,Vapi, Indoco Remedies Ltd,Mumbai and SAIF,Panjab University,Chandigarh for providing IR spectral data, Mass Spectra data and NMR spectral data respectively .<smiles>Oc1cccc2ccccc12</smiles>

naphthalen-1-ol

(1)
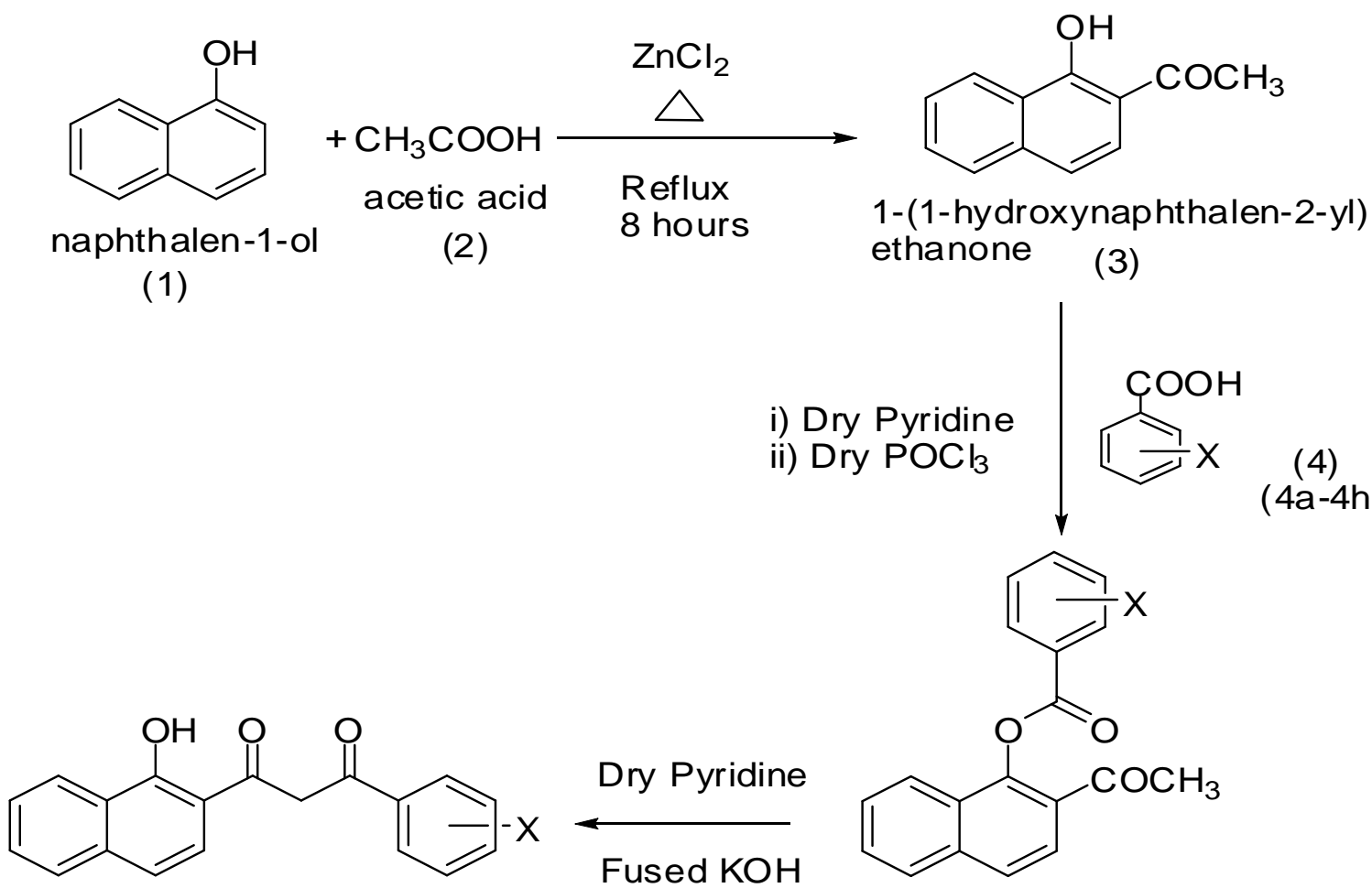

1 -(1-hydroxynaphthalen-2-yl)-3substituted propane-1,3-dione $(6 a-6 h)$<smiles>[X]c1ccc(-c2cc(-c3ccc4ccccc4c3O)n[nH]2)cc1</smiles>

2-(5-substitutedl-1 H-pyrazol-3-yl) naphthalen-1-ol

$(7 \mathrm{a}-7 \mathrm{~h})$ 
<smiles>O=C(O)c1ccccc1</smiles>

4(a)<smiles>O=C(O)c1ccc(Br)cc1</smiles>

4(b)<smiles>O=C(O)c1ccc(F)cc1</smiles>

4(c)<smiles>O=C(O)c1ccccc1Cl</smiles>

4(d)<smiles>Cc1ccc(C(=O)O)cc1</smiles>

4(e)<smiles>O=C(O)c1cccc([N+](=O)[O-])c1</smiles>

$4(f)$<smiles>O=C(O)c1cc([N+](=O)[O-])cc([N+](=O)[O-])c1</smiles>

4(h)<smiles>[X]c1ccc(-c2cc(-c3ccc4ccccc4c3O)n[nH]2)cc1</smiles>

(7)

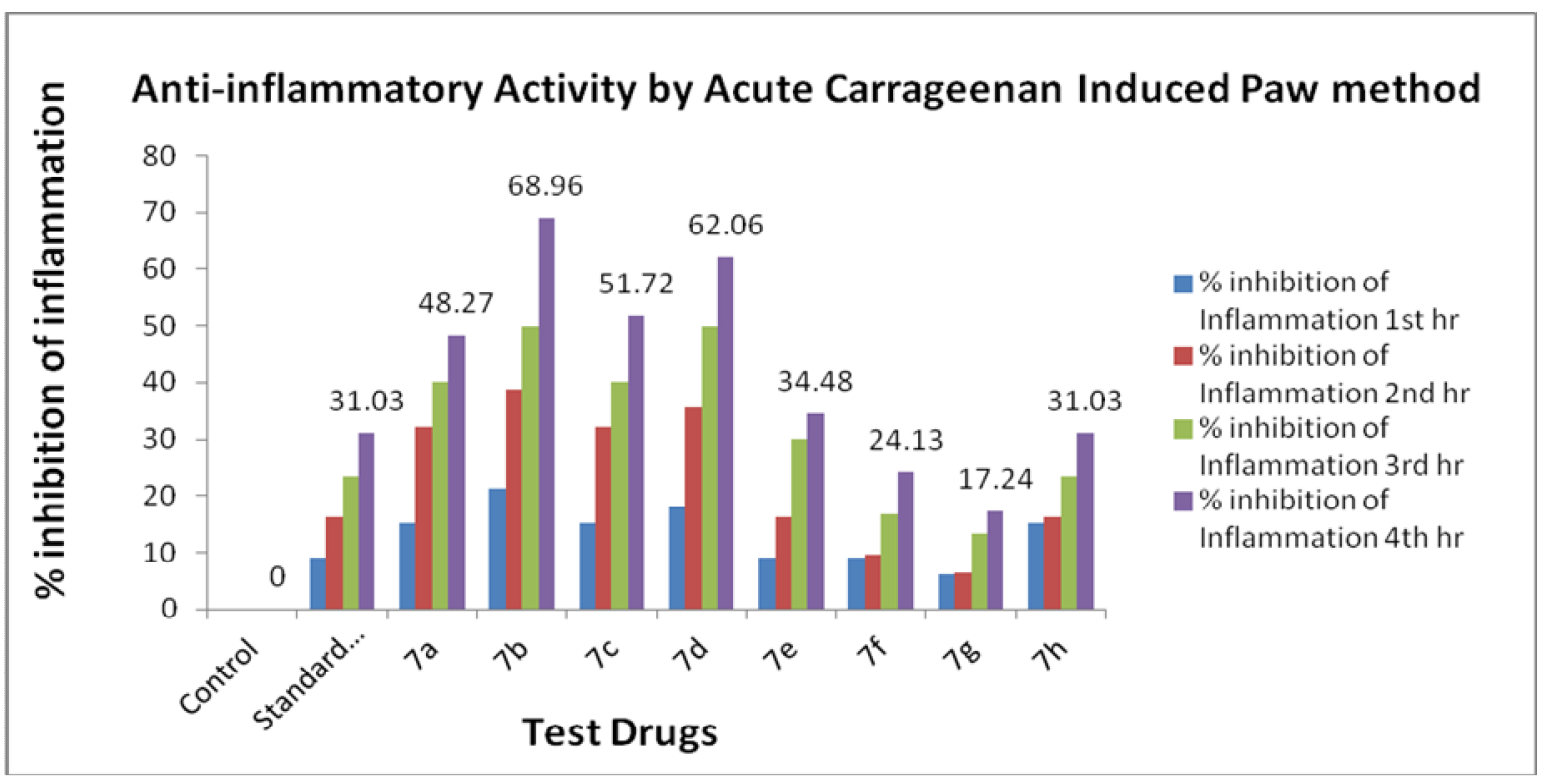

Fig. 1: Comparison of Anti-inflammatory activity between Indomethacin \& Test Drugs.

\section{REFERNCES}

Adnan A. Bekhit, Hayam M.A. Ashour and Yasser S. Abdel Ghany, "Synthesis and biological evaluation of some thiazolyl and thiadiazolyl derivatives of $1 \mathrm{H}$-pyrazole as anti-inflammatory antimicrobial agents", Eur J. Med Chem, 2008, 43, 456-463

Alka Chauhan and P. K. Sharma, "Pyrazole: A Versatile Moiety”, Intl J of Chem Tech Res , 2011, 3, 11-17

Amal. M. Youssef, Edward G. Neeland and Erika B. Villanueva, "Synthesis and biological evaluation of novel pyrazole compounds", Bioorg. Med. Chem , 2010, 18 , 5685-5696

Anna L. Blobaum and Lawrence J. Marnett, "Structural and Functional Basis of Cyclooxygenase Inhibition", Journal of Medicinal Chemistry, 2007, 50, 1425-1438

Cuzzocrea Salvatore, "Shock, inflammation and PARP", Pharm. Res., 2005, 52, 72-82

Deepak V. Dekhane, Shivaji S. Pawar and Sunil Gupta, "Synthesis and anti-inflammatory activity of some new 4,5-dihydro-1,5diaryl- 1H-pyrazole-3-substituted-heteroazole derivatives", Bioorg. Med. Chem Lett, 2011, 21, 6527-6532

Deepika vyawhare and Anna Pratima, "Green synthesis and pharmacological screening of 1,5-benzothiazepines as CNS agents, International journal of pharmacy and pharmaceutical sciences , 2010, 2 , 27-29

Flora F. Barsoum and Adel S. Girgis, "Facile synthesis of bis(4,5-dihydro-1H-pyrazole-1-carboxamides) and their thio-analogues of potential PGE2 inhibitory properties", Eur J. Med Chem,2009,44 , 21722177.
Hans Gergard Vogel, Drug discovery and evaluation: Pharmacological Assay, 3rd edn, Springer-Verlag Berlin Heidelberg New York, (2008) 1103

J. R. Vane and Y. S. Bakhle, "CYCLOOXYGENASES 1 AND 2", Annu. Rev. Pharmacol. Toxicol, 1998, 38, 97-120

Joan Feixas and Juan-Miguel Jimenez, "Naphthalene Derivatives: A New Series of Selective Cyclooxygenase-2 Inhibitors", Bioorg. Med. Chem Letters, 2001, 11, 2687-2690

Kensuke Kobayashi, Minaho Uchiyama and Hirokatsu Ito, "Discovery of novel aryl pyrazole series as potent and selective opioid receptor-like 1 (ORL1) antagonists", Bioorg. Med. Chem Lett, 2009, 19, $3627-3631$

Kunal Nepali and Gurinderdeepsingh, "A rational approach for the design and synthesis of 1-acetyl-3,5-diaryl-4,5-dihydro(1H)pyrazoles as a new class of potential non-purine xanthine oxidase inhibitors" Bioorg. Med. Chem , 2011 , 19, 1950-1958

Lake AW. Naphthalene derivatives having anti-inflammatory activity. U.S.Patent 4,061,779.

Lars Engman, David Stern, Håkan Frisell and Kerstin Vessman, "Synthesis, antioxidant properties, biological activity and molecular modelling of a series of chalcogen analogues of the 5lipoxygenase inhibitor DuP 654" Bioorg. Med Chem., 1995, 9, 1255-1262

Lingaiah Nagarapu, Jhansi Mateti and Hanmant K. Gaikwad, "Synthesis and anti-inflammatory activity of some novel 3-phenyl-N-[3(4-phenylpiperazin-1yl)propyl]-1H-pyrazole-5-carboxamide Derivatives", Bioorg. Med. Chem Lett , 2011 , 21 , 4138-4140 
Mohd Amir and Shikha Kumar. " Synthesis and Antiinflammatory, Analgesic , Ulcerogenic and Lipid Peroxidation activities of 3,5-dimethyl pyrazole , 3-methyl pyra-5-zolone and 3,5-disubstituted pyrazolines", Indian Journal Of Chemistry, 44B, 2005 , 2532-2537

Nopporn Thasana and Somsak Ruchirawat, "The application of the Baker-Venkataraman rearrangement to the synthesis of benz $[b]$ indeno[2,1-e $]$ pyran-10,11-dione" , Tetrahedron lett , 2002,43 , $4515-4517$

Palwinder Singh and Anu Mittal, "Current Status of COX-2 Inhibitors" Mini-Reviews in Medicinal Chemistry, 2008, 8, 73-90

Rajini Girdhar and Riyaj Tamboli. "Assessment of antiplatelet activity of 2-aminopyrimidines" Eur J. Med Chem, , 2012 , 50 , 428-432
Rang and M.M.Dale , Pharmacology, $5^{\text {th }}$ edn, Elsevier science Ltd, 2006, pp 217-241 \& 233

Sharma.S and T.Singh, "A study of novel anti-inflammatory derivatives of novel $\alpha$-amino naphthalene and $\beta$-amino naphthalene “, Archive de pharmazie , 2006, 339, 135-152

Subas.S.Sakya,Hengmiao Cheng and Kristin M. Lundy DeMello , "5-Heteroatom-substituted pyrazoles as canine COX-2 inhibitors: Part 2. Structure-activity relationship studies of 5-alkylethers and 5-thioethers", Bioorg. Med. Chem Lett, 2006, 16, 1202-1206

Winter C.A., Risely E.A. and Nuss G.W. Carrageenan-induced edema in hind paw of the rat as an assay for anti-inflammatory drugs. Proc Soc Exp Biol Med, 1962, 1, 544-546. 